\title{
Effect of Tourism Activities on Coral Communities at the Gulf of Suez, Red Sea
}

\author{
Mohamed Hamza Hasan \\ Aquatic Environment Department, Faculty of Fish Wealth, Suez University, Suez, Egypt \\ Email: marinehamza@yahoo.com
}

How to cite this paper: Hasan, M.H. (2018) Effect of Tourism Activities on Coral Communities at the Gulf of Suez, Red Sea. Journal of Water Resource and Protection, 10, 794-808.

https://doi.org/10.4236/jwarp.2018.108045

Received: July 12, 2018

Accepted: August 21, 2018

Published: August 24, 2018

Copyright $\odot 2018$ by author and Scientific Research Publishing Inc. This work is licensed under the Creative Commons Attribution International License (CC BY 4.0).

http://creativecommons.org/licenses/by/4.0/

\begin{abstract}
Although the rapidly expanding tourism industry is considered an extremely important economic activity, it caused increasing pressure on coral reefs of Egypt. Damage occurs from both direct and indirect impacts of tourism activities on coral communities. The Gulf of Suez has increasing of resorts from 8 at 2000 to 31 at 2014. This affected the coral communities along the area of study leads to a decrease in coral areas from $960 \mathrm{~m}^{2}$ at 2000 to $750 \mathrm{~m}^{2}$ at 2014, number of coral species from 21 species at 2000 to only 14 species at 2014, percentage cover of life coral from $46.4 \%$ at 2000 to $10.6 \%$ at 2014 ; on contrary, dead coral increased from $23.8 \%$ to $47.9 \%$ at the same period. This accompanied with an increase in the percentage of the algal cover from $8.6 \%$ at 2000 to $19.4 \%$ at 2014 . The statistical analysis revealed a high correlation between the increased tourism activities and the coral status variables measured during the study. The data obtained showed high significant positive and negative correlation between the different variables that determined according to the effect of the different variables on each other and the relation between them. The simple linear regression statistical analyses showed a significant effect of tourism activities on the coral status, the analyses indicated that each increase in number of resorts by one resort leads to significant decrease in total coral area at the site by $0.9 \%$, the analysis also showed that $80 \%$ of that decrease referred to the effect of tourism activities and $20 \%$ referred to other reasons. The analysis of variance (ANOVA) divided the recoded coral species into three categories, the first is soft corals which recorded significant increase in percentage cover from 2000 to 2014, the second is three species that recorded insignificant difference during the period of study, while the third category include most of the recorded species and they showed significant decrease in their percentage cover along time of study. The data obtained illustrated that all the investigated coral parameters are affected by the increasing tourism activities.
\end{abstract}

\section{Keywords}

Tourism Activities, Tourism Resorts, Coral Communities, Coral Status, Life 


\section{Introduction}

Coral reefs are productive and diverse ecosystems characterized by a huge biodiversity and a high level of endemism as found at the Red Sea [1]. The high productivity of coral ecosystems are well known even they are surrounded by water poor in nutrients necessary for primary production [2]. As it is a very productive ecosystem, it provided food and subsequently shelter for a large number of individuals and species leading to a complex interaction inside the ecosystem [3], led to a sensitive ecosystem affected by any minor change which could cause a degradation of the overall ecosystem. The spectacular coral reef areas found in Egypt make it ideally for the fast-growing tourist market.

As coral reefs are main fishing grounds and attractors of large numbers of tourists, they generate important contributions to the national income of many countries. Coral reefs are important source of economy whether they are used directly or indirectly or even from non use value [4]. Despite this natural wealth and socio-economic advantages, many threats are posing stress on coral reefs. Anthropogenic disturbances as tourism-related threats caused vast majority of long-term decreases in coral health and cover [5]. Human activities have destroyed the coral reef habitats and cause a reduction in coral cover by more than 50 per cent at most reefs [6]. If current degradation continues unabated, more than half of the world's coral reefs may be destroyed during the next 30 years [7].

The Egyptian coral reefs were at risk from human impacts; about $61 \%$ of the corals were greatly affected as was estimated by the World Resources Institute [8]. Along with the income generated by coral reef tourism to economy, it comes a series of destructive threats to the ecosystem. While the intact reefs are prime assets for Egyptian tourism, it is also the single cause of reef degradation. Egyptian Red Sea's live coral cover has been seriously declined over the last two decades [9]. The damage is caused by tourism use of reefs. In this respect, tourism is a double-edged sword as direct damage (trampling, breaking of corals by divers, etc.) and through tourism facilities (sewage; run-off, sedimentation, coastal alteration etc.). The damage caused by divers/snorkelers on corals reefs can take several forms, such as Kicking or brushing with the fins, use of hands, standing on corals, grabbing corals to pull themselves through the water, hitting coral with the SCUBA tank or other pieces of equipment, and also the creation of sediment clouds ([10] [11] [12]).

As a result of increasing the number of scuba divers, coral reefs related to tourism are expanding worldwide [13]. The destructive effect of mass tourism on corals was evident at four coral sites near Hurghada that showed a high physical damage in coral when exposed to mass tourism [14]. This damaged re- 
flected by lower frequency of hard coral (especially Acropora), higher percentage of algae and higher percent of soft coral. Also the same authors reported that a control site away from tourism showed no damaged.

A study by Abou Zaid [15] showed that coral cover was decline when the number of divers exceeds the area's carrying capacity. He reported a gradual decline in coral cover over. He also concluded that as maximum as 10,000 dives per site seems to prevent serious degradation. Boat Anchoring and grounding is one of the serious damage correlated with tourism activities. In Sharm El Sheikh, the dive boats caused a high damage to the reef when increased from 26 at 1988 to 320 at 2000 [15].

Although tourism is an important source of fund in Egypt, it considers the greatest threat to corals reefs [9]. Because of these conflicting characteristics, coral areas must be managed in terms of tourism. In this respect, an ecological model has been used. The model consists of five important indicators that represent environmental characteristics of a coral reef. These indicators are coral cover, Live to dead coral ratio, coral biodiversity, non-living substrates and macro algae cover. The Threats to these indicators were incorporated by this model. Also the resilience of and reproductive capability of the reef, were tested over a time period.

Although a lot of research has already been done on coral reefs and their degradation, there is still a critical need for detailed monitoring and assessment of reef habitats in order to better document where and how coral reefs are threatened and to understand what measures are needed to safeguard them.

This study aims to evaluate the different impact of tourism resorts at the Gulf of Suez on the coral reef areas over a 14 years period.

\section{Materials and Methods}

\subsection{Site Description}

The Gulf of Suez is a part from the Red Sea, the gulf has temperate characters since the extensive sandy bottom, and relatively shallow depths compared to the adjacent Red sea and Gulf of Aqaba. Gulf of Suez faces a lot of challenges since it is a dumped over and many pollutants as oil from oil refinery companies at its banks and oil fields inside the Gulf.

The gulf was formed within a relatively young but now inactive rift basin, dating back about 28 million years. It stretches some $300 \mathrm{~km}$ north by northwest, terminating at the Egyptian city of Suez and the entrance to the Suez Canal. The length of the gulf is $314 \mathrm{Km}$ and it varies in width from 19 to $32 \mathrm{Km}$ and average depth $40 \mathrm{~m}$ with a max depth of $70 \mathrm{~m}$.

Twenty sites at Ain Sukhna area in the western Gulf of Suez were surveyed along distance of $50 \mathrm{~km}$. The survey was conducted throughout the period 2000 to 2014. The sites were determined by fixing more or less equal distances between them, however determining the position of sites was done during the preliminary survey. The area of study is shown in Figure 1. 


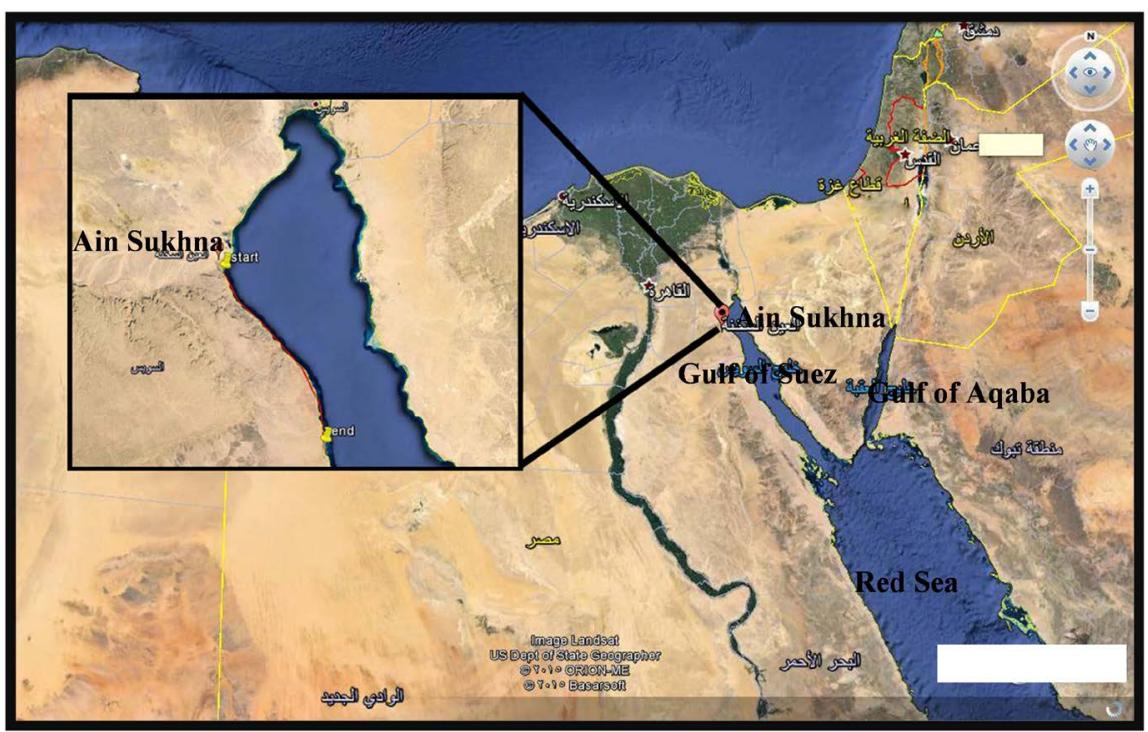

Figure 1. The study area at the north-western Gulf of Suez.

The area of study is characterized by scattered coral patches and a heave tourism resorts.

\subsection{Survey Coral Ecosystem}

Data collected using Belt transect method ([16] [17]). In this method, a transect lines were employed to act as guides along which $1 \mathrm{~m}$ quadrate was placed every meter continuously, or at regular intervals (usually $2 \mathrm{~m}$ apart) depending on the transect length and the reef profile. Transects were located parallel to each other and to the Shoreline. The quadrate was made of aluminum pipe and divided into 100 squares with nylon line, and each square therefore represented $1 \%$ of the quadrate.

The following attributes were recorded' in each quadrate: total number of coral species; total number of colonies; abundance of each species; living coverage of each species (\%); living coverage of hard corals, soft corals and microalgae (fleshy and turf algae); dead corals cover (\%); Bare substratum (\%). These attributes were again calculated at the level of each reef site.

\subsection{Statistical Analysis}

We used SPSS statistical program to carry out the statistical analysis for the obtained data [18]. Statistical analyses were used to examine relationships between the number of resorts and the total coral area, the life coral, dead coral, hard coral, soft corals and algae at the study site. We used simple linear regression to explore the relationships between the independent variable (Number of resorts) and the dependent variables. We also used Person's correlation coefficient to examine the degree of correlation between the different parameters investigated. Finally we used Time Series Analyses to forecast the future situation at the area if the current conditions are ongoing. 


\section{Result}

\subsection{Tourism Activities}

Tourism in the Gulf of Suez, Egyptian Red Sea has been growing at an amazing rate over the last two decades (Table 1).

The number of resorts in the Gulf of Suez has increased from 8 in 2000 to 31 in 2014, while the number of visitors increased from 12,629 to 98,959 . In 2000 , there were only 8 resorts, and a total of 12,629 persons visited the area. The tourism activities increased $\mathrm{n}$ the following years, nearly doubled the number of resorts to reach 15 resorts in 2003, with a total of 30,170 gusts. The increase in both number of resorts and visitors continued during the years to reach 31 resorts with a total of 98,959 gusts visited the area.

\subsection{Coral Status}

The number of coral patches at the area gradually decreased from 32 patches at 2000 to 25 patches at 2014. The areas of these patches showed the same pattern of decrease from $960 \mathrm{~m}^{2}$ at 2000 to $750 \mathrm{~m}^{2}$ at 2014 (Figure 2).

The percentage cover of life and dead coral as well as the consolidated non-living substrates were investigated during the current study. The data obtained showed remarkable differences during the period of study, while life coral cover showed its maximum percentage during year 2000 (46.4\%), it gradually decreased during the following years from $40.1 \%$ at $2003,38.5 \%$ at $2005,12.1 \%$ at 2011 , reached its minimum cover $(10.6 \%)$ at 2014 . Also rocky areas exhibit the same pattern as life coral cover decreased from $15.3 \%$ at 2000 to $7.2 \%$ at 2014 . On contrary, dead coral cover showed percentage increase from $23.8 \%$ at 2000 to $47.9 \%$ at 2014 , with the same pattern algal cover at the area increased from $8.6 \%$ at 2000 to $17.4 \%$ at 2014 , percentage of rubble increased from $5.9 \%$ at 2000 to $12.2 \%$ at 2014 and percentage of sand that appeared for the first time at 2005 recorded $0.5 \%$ from the total area of study to $4.7 \%$ at 2014 (Figure 3).

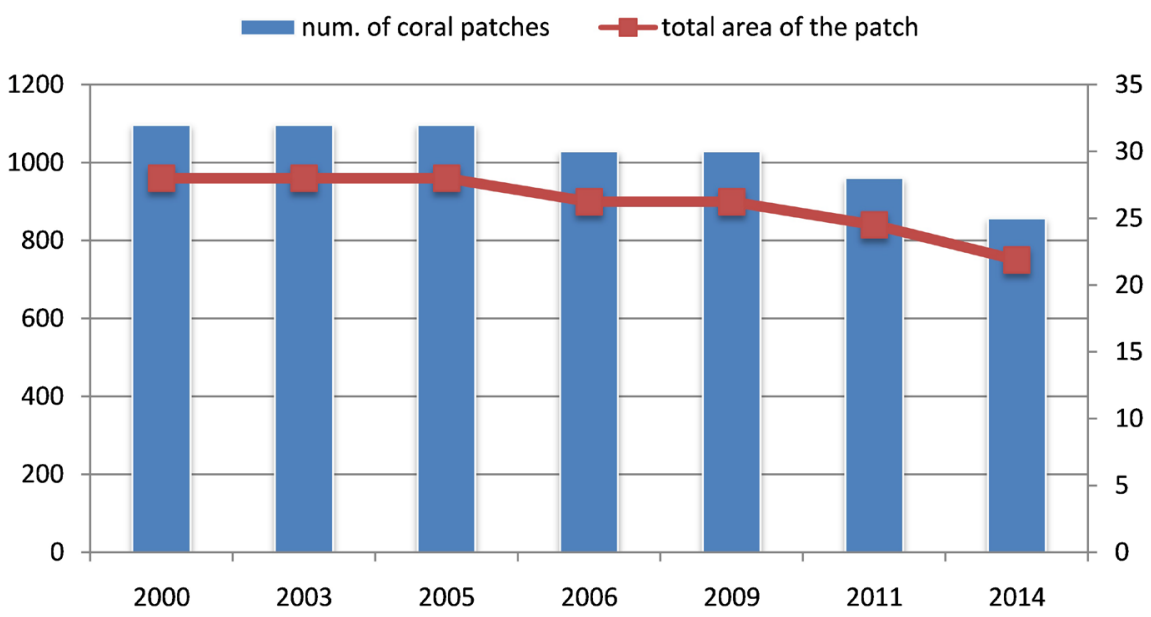

Figure 2. The number of coral patches and patches area recorded at the study area. 


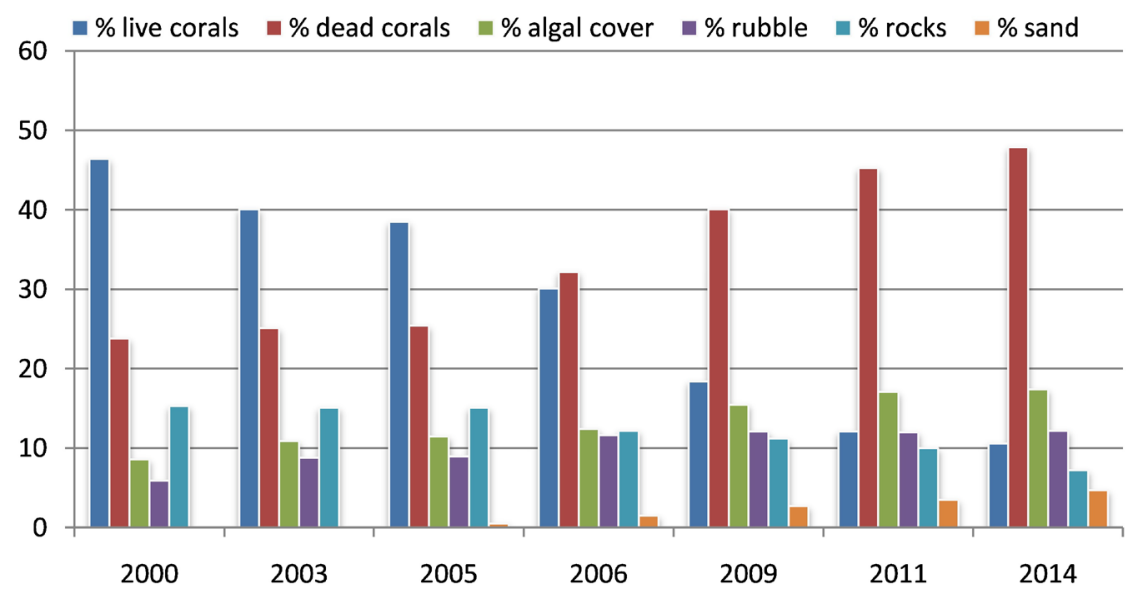

Figure 3. Percentage of life and dead coral, algal cover, rubbles, rocks and sand at the area of study during the period from 2000 to 2014 .

Table 1. The number of tourism resorts and visitors at the Gulf of Suez at the eriod from 2000 to 2014.

\begin{tabular}{cccccccc}
\hline & 2000 & 2003 & 2005 & 2006 & 2009 & 2011 & 2014 \\
\hline No. of compounds & 8 & 15 & 18 & 18 & 21 & 28 & 31 \\
No. of visitors & 12,629 & 30,170 & 39,124 & 40,535 & 46,607 & 78,835 & 98,959 \\
\hline
\end{tabular}

The most obvious difference was in the mean percentage cover of hard and soft corals which indicated the status of the coral areas. The hard corals recorded the highest percentage at $2000(89.5 \%)$ from this percentage $56 \%$ were branched coral and $44 \%$ unbranched corals, gradually decreased to $85.3 \%$ at 2003 (58\% branched and 42 unbranched), the reduction in hrd coral cover in the area contiued till recorded its lowest percentage (65.9\%) at 2014, from this percentage $94 \%$ was branched corals and only $6 \%$ unbranched. While soft corals recorded an opposite patterns as its cover increased over the years of study, it recorded $10.5 \%$ at 2000 , increased to $18.4 \%$ at 2006 and reached its maximum cover (34.1\%) at 2014 (Figure 4).

\subsection{Coral Diversity}

A total of 21 coral species were recorded during the study period, 18 hard coral species and 3 soft coral. The species diversity decreased from 21 species at 2000 to 20 species at 2005, 17 species at 2006, while it recorded the lowest number of species (14 species) at 2014 (Table 2). The data revealed a high fluctuation in percentage cover depend on the species. The 3 soft coral species recorded increase in their percentage cover from $1.09 \%$ at 2000 to $4.57 \%$ at 2014 for Xenia macrospiculata. Sarcophyton trocheliophorum increased from $2.87 \%$ at 2000 to $7.12 \%$ at 2014 , Dindrophyllia robusta increased from $1.15 \%$ at 2000 to $6.44 \%$ at 2014. The three species showed significant difference in their percentage cover during the period of study. On contrary, 5 hard coral species showed insignifi- 
cant differences in their percentage cover during the years of study, those species are Stylophora pistillata recorded $7.42 \%$ at 2000 and $7.81 \%$ at 2014 , Acropora valida recorded $3.71 \%$ at 2000 and $2.75 \%$ at 2014 , A. humilis recorded $2.3 \%$ at 2000 and $2.38 \%$ at 2004 and $A$. hemprichi recorded $3.6 \%$ at 2000 and $3.47 \%$ at 2014 and $A$. pharaonis that recorded $8.4 \%$ at 2000 and $8.28 \%$ at 2014 , indicating these species didn't affected by tourism impact on the area. While 13 hard coral species showed highly significant difference during the period of study. They showed a highly decrease in percentage cover from 2000 to 2014.

The study revealed that the tolerable of species recorded are different from species to species according to the sensitivity of the species towards the impact occurred. The species not only showed a decrease in their percentage cover but some of the species completely disappeared from the area at different year depends on their tolerability. The first species disappeared was Millepora platyphylla which disappeared at 2005, followed by three species disappeared at 2006; these were Millepora dichotoma, Pocillopora verrucosa, Favia stelligera. Finally three species were disappeared at 2014; these were Acropora nobilis, Platygyra lamellina and Galaxea fascicularis (Table 2).

\subsection{Statistical Analyses}

\subsubsection{Simple Linear Regression}

The simple linear regression analyses showed the relation between the number of tourism resorts at the Gulf of Suez as an independent variable and the coral status at the same area. The number of resorts increased during the period from 2000 to 2014, which affect the coral status (Table 3).

The simple linear regression statistical analyses showed a significant effect of tourism activities on the coral status; the analyses indicated that each increase in number of resorts by one resort leads to significant decrease in total coral area at the site by $0.9 \%$; the analysis also showed that $80 \%$ of that decrease referred to the effect of tourism activities and $20 \%$ referred to other reasons. The relation between the number of resort and life corals showed that each one resort increase leads to a significant decrease in life coral by $1.7 \%$. The result indicated that $89 \%$ in life coral percentage decrease referred to the effect of tourism activities and only $11 \%$ referred to other reasons. On the other hand, the dead coral showed significant percentage increase by $1.2 \%$ each one resort increase. The analyses showed that $85 \%$ in dead coral percentage increased referred to the effect of tourism and only $15 \%$ referred to other reasons.

\subsubsection{Person's Correlation Coefficient}

The data obtained showed high significant positive and negative correlation between the different variables that determined according to the effect of the different variables on each other and the relation between them. As shown in Table 4 , there were a high significant positive correlation between the number of resorts and the percentage cover of dead corals and algae recorded $+0.924^{* *}$ and $+0.979^{* *}$ respectively. Contrary, there was a highly significant negative correla- 
tion between the number of resorts and coral areas, life corals and hard coral recorded $-0.896,-0.943$ and -0.979 , respectively. This result indicated the adverse effect of the growing tourism activities on the health of coral communities in the area.

\subsubsection{Time Series Analysis}

The time series analysis was conducted during the current study to forecast the coral status and degradation if the current tourism activities continued at the same rate (Table 5). The analysis forecast that if the tourism activities continued at the same rate, there will be a decline in coral areas from $750 \mathrm{~m}^{2}$ recorded at 2014 to $530 \mathrm{~m}^{2}$ at 2022, Also the percentage of life corals will decreased by $54.6 \%$ during these nine years, meaning that life coral will disappear long before year 2022.

Table 2. Percentage cover of coral species recorded during the current study and their significance differnce during the period from 2000 to 2014.

\begin{tabular}{|c|c|c|c|c|c|c|c|c|c|}
\hline species & 2000 & 2003 & 2005 & 2006 & 2009 & 2011 & 2014 & P-Value & \\
\hline Xenia macrospiculata & 1.09 & 1.21 & 1.34 & 1.69 & 2.26 & 3.78 & 4.57 & 0.0019 & Sig. dif. \\
\hline Sarcophyton trocheliophorum & 2.87 & 3.19 & 3.88 & 4.25 & 5.68 & 6.92 & 7.12 & $1.95 \mathrm{E}-04$ & Sig. dif. \\
\hline Dindrophyllia robusta & 1.15 & 1.89 & 2.3 & 2.79 & 4.12 & 5.66 & 6.44 & $<0.0001$ & Sig. dif. \\
\hline Stylophora pistillata & 7.42 & 7.53 & 7.34 & 7.09 & 7.98 & 7.05 & 7.81 & 0.59454 & insig. dif. \\
\hline Acropora valida & 3.71 & 3.69 & 2.94 & 2.18 & 2.32 & 2.69 & 2.75 & 0.11944 & insig. dif. \\
\hline A. humilis & 2.3 & 2.32 & 2.3 & 2.27 & 2.24 & 2.39 & 2.38 & 0.2713 & insig. dif. \\
\hline A. hemprichi & 3.6 & 3.71 & 3.65 & 3.47 & 3.5 & 3.52 & 3.47 & 0.0868 & insig. dif. \\
\hline A. pharaonis & 8.4 & 8.51 & 8.45 & 8.18 & 8.32 & 8.24 & 8.28 & 0.16251 & insig. dif. \\
\hline A. nobilis & 2.81 & 2.8 & 1.35 & 1.22 & 0.81 & 0.08 & 0 & 0.00108 & Sig. dif. \\
\hline A. forskali & 3.15 & 3.17 & 2.41 & 2.2 & 1.31 & 1.01 & 0.61 & $1.65 \mathrm{E}-04$ & Sig. dif. \\
\hline Porites solida & 4.2 & 4.24 & 2.85 & 2.44 & 1.23 & 0.86 & 0.41 & $3.46 \mathrm{E}-04$ & Sig. dif. \\
\hline Porites lutea & 4.18 & 4.21 & 3.02 & 2.28 & 1.12 & 0.71 & 0.23 & $3.39 \mathrm{E}-04$ & Sig. dif. \\
\hline Platygyra lamellina & 1.64 & 1.6 & 1.1 & 0.65 & 0.31 & 0.05 & 0 & $7.86 \mathrm{E}-04$ & Sig. dif. \\
\hline Echinopora gemmacea & 1.95 & 1.98 & 1.81 & 1.73 & 1.63 & 1.52 & 1.54 & 0.00138 & Sig. dif. \\
\hline E. fruticulosa & 2.74 & 2.7 & 2.14 & 2.06 & 1.54 & 1.02 & 0.88 & $1.46 \mathrm{E}-04$ & Sig. dif. \\
\hline Galaxea fascicularis & 3.09 & 3.15 & 2.61 & 2.45 & 0.9 & 0.25 & 0 & $8.36 \mathrm{E}-04$ & Sig. dif. \\
\hline Lobophyllia carymbosa & 2.94 & 2.86 & 1.79 & 1.6 & 0.4 & 0.26 & 0.19 & $9.67 \mathrm{E}-04$ & Sig. dif. \\
\hline Millepora dichotoma & 0.21 & 0.23 & 0.05 & 0 & 0 & 0 & 0 & 0.0292 & Sig. dif. \\
\hline M. platyphylla & 0.11 & 0.11 & 0 & 0 & 0 & 0 & 0 & 0.04706 & Sig. dif. \\
\hline Pocillopora verrucosa & 1.01 & 0.97 & 0.11 & 0 & 0 & 0 & 0 & 0.03288 & Sig. dif. \\
\hline Favia stelligera & 0.95 & 0.91 & 0.21 & 0 & 0 & 0 & 0 & 0.02401 & Sig. dif. \\
\hline
\end{tabular}


Table 3. Analysis of Simple linear regression for the relation between tourism activities (number of resorts) and coral status at the Gulf of Suez.

\begin{tabular}{|c|c|c|c|c|}
\hline No. & Equation & dependent & independent & $\mathrm{R}^{2}$ \\
\hline 1 & $\begin{array}{c}\mathrm{Yi}=1074.8-9.02 \mathrm{Xi} 1 \\
\quad(25.5)^{* *}(-4.52)^{\star *}\end{array}$ & Coral Area $\left(\mathrm{m}^{2}\right)$ & number of Resorts & $80 \%$ \\
\hline 2 & $\begin{array}{c}\mathrm{Yi}=63.76-1.74 \mathrm{Xi} 2 \\
(10.8)^{\star *}(-6.35)^{* *}\end{array}$ & Live Coral (\%) & number of Resorts & $89 \%$ \\
\hline 3 & $\begin{aligned} \mathrm{Yi}= & 10.32+1.20 \mathrm{Xi} 3 \\
& (2.18)(5.38)^{\star *}\end{aligned}$ & $\begin{array}{l}\text { Dead Coral } \\
\quad(\%)\end{array}$ & number of Resorts & $85 \%$ \\
\hline 4 & $\begin{array}{c}\mathrm{Yi}=5.05+0.418 \mathrm{Xi} 4 \\
\quad(4.7)^{\star *}(8.21)^{\star *}\end{array}$ & $\begin{array}{l}\text { Algae } \\
(\%)\end{array}$ & number of Resorts & $93 \%$ \\
\hline 5 & $\begin{array}{c}\mathrm{Yi}=-0.62+1.09 \mathrm{Xi} 5 \\
\quad(-0.28)(10.64)^{\star *}\end{array}$ & $\begin{array}{l}\text { Soft coral } \\
(\%)\end{array}$ & number of Resorts & $85 \%$ \\
\hline 6 & $\begin{aligned} \mathrm{Yi}= & 100.62-1.09 \mathrm{Xi} 6 \\
& (46.2)(-10.6)^{* *}\end{aligned}$ & $\begin{array}{l}\text { hard coral } \\
\quad(\%)\end{array}$ & number of Resorts & $95 \%$ \\
\hline
\end{tabular}

$\mathrm{Yi}=$ Number of Resorts. Xi1 $=$ Coral Area $\left(\mathrm{m}^{2}\right)$, Xi2 $=$ Live Coral, $\mathrm{Xi} 3=$ Dead Coral, Xi4 $=$ Algae, $\mathrm{Xi} 5=$ Soft coral, Xi6 $=$ Hard coral I $=$ Number of observation $1 \ldots 10 . \mathrm{R}^{2}=$ Co efficient of determination. ${ }^{*}$ Significant on 0.01 .

Table 4. Analyses of correlation between different variables used in the current study by Person's correlation coefficient.

\begin{tabular}{|c|c|c|c|c|c|c|c|c|}
\hline & & Resorts & Coral area & live Coral & Dead Coral & Algae & Soft Coral & Hard Coral \\
\hline & Pearson Correlation & 1 & $-0.896-^{* *}$ & $-0.943-^{* *}$ & $0.924^{\star \star}$ & $0.965^{\star \star}$ & $0.979^{* *}$ & $-0.979-* *$ \\
\hline \multirow[t]{3}{*}{ Resorts } & Sig. (2-tailed) & & 0.006 & 0.001 & 0.003 & 0.000 & 0.000 & 0.000 \\
\hline & $\mathrm{N}$ & 7 & 7 & 7 & 7 & 7 & 7 & 7 \\
\hline & Pearson Correlation & $-0.8966^{* *}$ & 1 & $0.890^{* *}$ & $-0.927-* *$ & $-0.870-^{\star}$ & $-0.942-^{\star *}$ & $0.942^{* *}$ \\
\hline \multirow[t]{3}{*}{ Area } & Sig. (2-tailed) & 0.006 & & 0.007 & 0.003 & 0.011 & 0.001 & 0.001 \\
\hline & $\mathrm{N}$ & 7 & 7 & 7 & 7 & 7 & 7 & 7 \\
\hline & Pearson Correlation & $-0.943-^{* *}$ & $0.890^{* *}$ & 1 & $-0.990-^{* *}$ & $-0.993-^{* *}$ & $-0.975-^{* *}$ & $0.975^{* *}$ \\
\hline \multirow[t]{3}{*}{ live Coral } & Sig. (2-tailed) & 0.001 & 0.007 & & 0.000 & 0.000 & 0.000 & 0.000 \\
\hline & $\mathrm{N}$ & 7 & 7 & 7 & 7 & 7 & 7 & 7 \\
\hline & Pearson Correlation & $0.924^{\star *}$ & $-0.927-* *$ & $-0.990-^{\star *}$ & 1 & $0.974^{\star \star}$ & $0.978^{\star *}$ & $-0.978-* \star$ \\
\hline \multirow[t]{3}{*}{ Dead Coral } & Sig. (2-tailed) & 0.003 & 0.003 & 0.000 & & 0.000 & 0.000 & 0.000 \\
\hline & $\mathrm{N}$ & 7 & 7 & 7 & 7 & 7 & 7 & 7 \\
\hline & Pearson Correlation & $0.965^{* *}$ & $-0.870-^{\star}$ & $-0.993-^{* *}$ & $0.974^{* *}$ & 1 & $0.979^{* *}$ & $-0.979-* *$ \\
\hline \multirow[t]{3}{*}{ Algae } & Sig. (2-tailed) & 0.000 & 0.011 & 0.000 & 0.000 & & 0.000 & 0.000 \\
\hline & $\mathrm{N}$ & 7 & 7 & 7 & 7 & 7 & 7 & 7 \\
\hline & Pearson Correlation & $0.979^{* *}$ & $-0.942-* *$ & $-0.975-* *$ & $0.978^{\star *}$ & $0.979^{* *}$ & 1 & $-1.000-* *$ \\
\hline \multirow[t]{3}{*}{ Soft Coral } & Sig. (2-tailed) & 0.000 & 0.001 & 0.000 & 0.000 & 0.000 & & 0.000 \\
\hline & $\mathrm{N}$ & 7 & 7 & 7 & 7 & 7 & 7 & 7 \\
\hline & Pearson Correlation & $-0.979-* *$ & $0.942^{\star \star}$ & $0.975^{\star \star}$ & $-0.978-^{* *}$ & $-0.979-* *$ & $-1.000-^{* *}$ & 1 \\
\hline \multirow[t]{2}{*}{ Hard Coral } & Sig. (2-tailed) & 0.000 & 0.001 & 0.000 & 0.000 & 0.000 & 0.000 & \\
\hline & $\mathrm{N}$ & 7 & 7 & 7 & 7 & 7 & 7 & 7 \\
\hline
\end{tabular}

${ }^{*}$ Correlation is significant at the 0.01 level (2-tailed). ${ }^{*}$ Correlation is significant at the 0.05 level (2-tailed). 
Table 5. Forecast the coral status till year 2022 by using Time series analysis statistical program.

\begin{tabular}{cccc}
\hline No. & Equation & $\begin{array}{c}\text { Current value } \\
(2014)\end{array}$ & $\begin{array}{c}\text { Forecast value } \\
(2022)\end{array}$ \\
\hline 1 & $\begin{array}{r}\hat{\mathrm{Y}}_{\mathrm{i}}=1028.57-33.2 \hat{\mathrm{x}} \\
(35.4)^{* *}(-5.1)^{* *}\end{array}$ & $750 \mathrm{~m}^{2}$ & $530 \mathrm{~m}^{2}$ \\
\hline 2 & $\begin{array}{c}\hat{\mathrm{Y}}_{\mathrm{i}}=54.2-6.55 \hat{\mathrm{x}} \\
(21.4)^{* *}(-11.5)^{* *}\end{array}$ & $10.6 \%$ & $44 \%$ \\
\hline
\end{tabular}

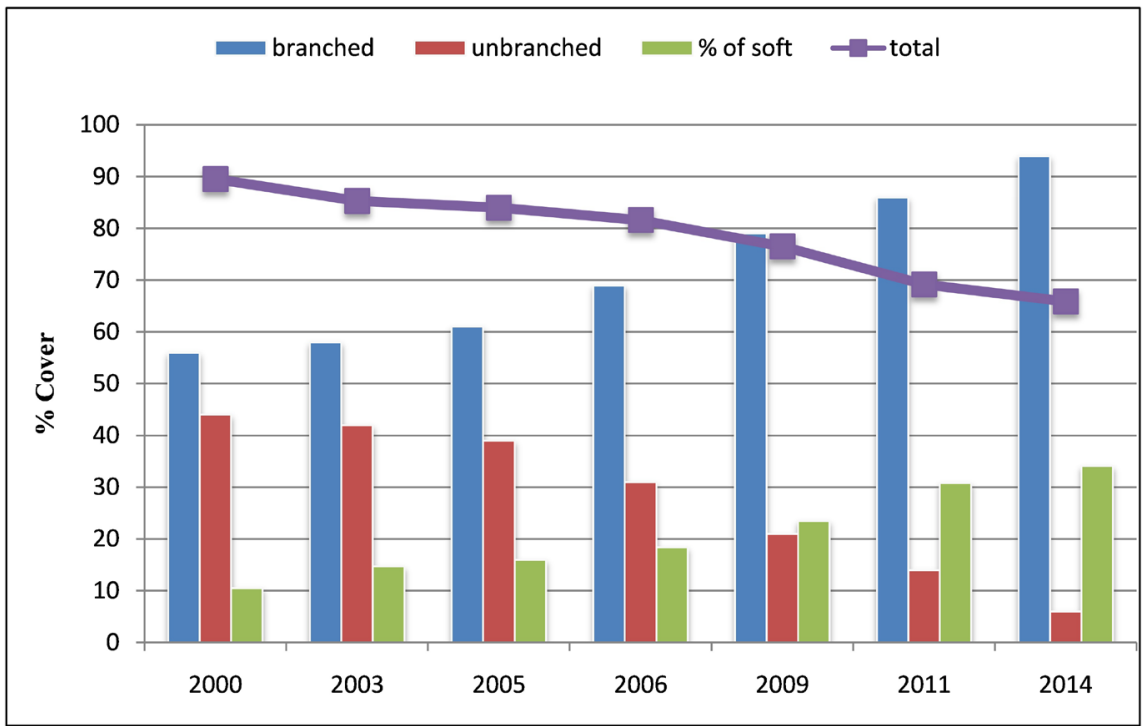

Figure 4. The percentage cover of hard and soft corals recorded at the study area during the period from 2000 to 2014 .

\section{Discussion}

Egyptian coral reefs characterized by astonishing biodiversity and high endemism [1]. It is very hard to determine its intrinsic value. There are aspects of biodiversity that can be measured and monetized, and tourism is one of these aspects as it depends mainly on the status of coral reefs.

The coastal zones of Gulf of Suez are undoubtedly under heavy use and the pressure will not cease in the foreseeable future given the expansion of the tourism industry and other developments. The number of tourists visiting Gulf of Suez is on the increase. Economically, the coastal zone is by far the most valuable segment of the Egyptian territory.

Coastal and marine resources are of vital importance to Egyptian socio-economic development. These resources have suffered from the process of development and are at risk from internal and external threats including climate change, sea level rise and tourism activities [5]. Action to protect these resources is a priority for current and future plans. The implantation of a growing tourism compounds will only add further pressure to the coastal zones and have adverse impacts on the marine ecosystem. 
There was no reef-related tourism in the Gulf of Suez till the end of the ninetieth, then the tourism activities begin to gradually increase, this accompanied with increasing adverse impact on the coral areas at the gulf, which directly affected by the tourism activities.

The state of the reef indicator grew by the time as a result of a complex relation between ecological and economic trends. Coral cover is the most valuable ecological reef indicator [19] that interacts with both the other ecological indicators and socio-economic variables. As found during the current study, there was a decrease in the life coral cover in the area accompanied with increase of dead coral cover and algal cover. This indicated that the coral areas is suffering from the tourism activities and the decline in all coral patches indicators were obvious. The decrease in coral diversity due to intensive tourism activities not only observed during the current study, but was also reported in many areas as in Hurghada, Red Sea [14]. The same situation was found in other areas in Egypt as in Sharm Elsheikh that showed a drop of coral cover from an average of $45 \%$ to around $12 \%$ [20]. This Loss of biodiversity has resulted in numerous impacts including economic, managerial, ecological, social, cultural and scientific consequences [21].

Eco-tourism related to coral reefs exploitation is expanding all over the world, this attributed to the increase number of SCUBA divers every year [13]. Divers can cause tissue abrasion, breakage, and mortality of corals [22]. In Considerable places of the world scuba diving is the main cause of coral reefs destructions ([11] [13] [23]). However, it was found that snorkeling was the worst tourism sea activity as found in Sembilan Islands, Malysia by AbdulRazek, et al. [6].

Tourism is the prime threat to Egyptian corals reefs. Egyptian Red Sea's live coral cover has been seriously declined over the last three decades, as a result of tourism use of coral reefs [24]. The data collected from the current study reached to the same conclusion at the Gulf of Suez, where the life coral cover was declined dramatically from $46.4 \%$ to only $10.6 \%$ during the 14 years the period of study, on contrary, the dead coral cover increased from $23.8 \%$ to $47.9 \%$. This was accompanied by the increase of soft coral cover at the expense of hard coral cover.

The physical destruction of tourism activities may cause these alterations in the coral status. The physical damaged to coral communities as a result of tourism activities can take several forms, such as standing on corals, brushing with the fins or Kicking, hitting coral with the SCUBA tank or other pieces of equipment, use of hands, grabbing corals to pull themselves through the water, and also the creation of sediment clouds ([10] [11] [12]). Among the direct impacts, there are coral broken by divers or snorkelers, trampling, damages from recreational boat grounding and anchoring. Riegl and Velimerov [25] found that coral breakage was the most common damage, especially on highly frequented reefs. Also, all observed damage was most frequent within the first ten meters depth, suggesting that major threats on coral reefs are produced by inexperienced di- 
vers and snorkelers rather than by experienced divers who practice a more eco-friendly tourism [26]. The result obtained from the current study is compatible with many researcher studies that scuba diving and snorkeling have empirically demonstrated can cause environmental damage to coral reefs and related coastal resources ([11] [12]).

The study of Jameson, et al. [14] at Hurghada, Red Sea confirmed the results obtained by the current study, and they concluded that the heavy tourism activities caused high physical damage to coral reefs compared to one intact site. The effect had reflected in a lower percentage of hard coral cover, higher percentage of algae and soft coral.

From what we have analyzed throughout this study, we can conclude that there was a significant decrease in coral status at the area of study and that tourism activities are responsible for $80 \%$ to $95 \%$ of the coral destruction.

Using the data presented in the current study, scenarios for a 22 -year time period (2000 to 2022) have been developed to predict the effect of tourism activities on the status of coral areas at the Gulf of Suez and highlight the trends if the area continues to develop at the current rates. The study predicted a decrease in coral area by $55 \%$ and in life coral by $10.6 \%$ if the current rate of exploitation was persisting. Other studies reached the same conclusion as Wilkinson [7], who concluded that if current degradation continues unabated in the next 30 years, and about half of the world's reefs may be destroyed. The same conclusion for the effect of anthropogenic impacts on coral reefs was reached by AbdulRazak et al. [6]. The Egyptian coral reefs were at risk from human impacts; about $61 \%$ of the corals were greatly affected as was estimated by the World Resources Institute [8]. Also in their work on human impact on coral reefs Al-Zibdah, et al. [27] found correlation analyses indicated that species richness increased with increasing distance from the industrial jetty.

It was concluded by the current study that by far the tourism attraction is the prime importance use of coral reefs, although they have value for other activities. Because the reefs are very important assets of eco-tourism, and because such tourism is a pivotal component of Egypt's strategy for tourism sustainability, it is indispensable that the reefs be protected from excessive use which could led to undermine a key asset for Egypt and its economy.

Unconstrained development along the Gulf of Suez will intensify tourism damage to coral areas. If the development continues at the current rates, economic benefits provided by coral reefs will be increased but only in the short-term. If the impact of unmanaged tourism continued to increase (over-development and over-use), the value of the reef will decrease over time [20]. In contrary, if suitable management is adopted, the value of reefs in the short-term will be reduced, but the overall net value will be sustained at current levels and will even rise slightly over time [20].

The study provides decision-makers with a cogent information that supports the investment in protection the reef health and managing the natural resource 
that supports tourism in the Gulf of Suez rather than the overexploitation of these resources.

\section{Conclusion}

The current study concluded that the tourism activities have a major effect on coral communities at the Gulf of Suez, Red sea. The destruction of corals continued during the period of study (14 years), and it is not stoppable as long as tourism activities continue to grow. In spite of the high revenue of tourism to the national income, it is only for the short term. If this tourism movement continued unmanaged, the income will greatly reduced and the loss of corals will be dramatic and unrestored. Action must be taken to manage the unleashed tourism activities in Egyptian Red Sea.

\section{Acknowledgements}

The author is deeply grateful to Dr. Mohamed El-Shahed for his great help in the statistical analysis of this manuscript.

\section{Conflicts of Interest}

The authors declare no conflicts of interest regarding the publication of this paper.

\section{References}

[1] Head, S.M. (1987) Corals and Coral Reefs of the Red Sea. In: Edwards, A.J. and Head, S.M., Eds., Key Environments: Red Sea, Pergamon Press, Oxford, 128-151. https://doi.org/10.1016/B978-0-08-028873-4.50012-8

[2] Hoegh-Guldberg, O. (2000) Climate Change, Coral Bleaching and the Future of the World's Coral Reefs. Greenpeace, Amsterdam, 27 p.

[3] Barrania, A. (2010) Cost of Degradation of Coral Reefs and Fisheries Caused by Tourism Development, Egypt's Red Sea A Case Study of Hurghada-Safaga Area. Institute of National Planning, Cairo, Egypt. http://kenanaonline.com/users/drBarrania/posts/119025

[4] Cesar, H. (2000) Collected Essays on the Economics of Coral Reefs. University of Kalmar, Kalmar, Sweden.

[5] Hughes, T.P. (2003) Climate Change, Human Impacts, and the Resilience of Coral Reefs. Science, 301, 929-933. https://doi.org/10.1126/science.1085046

[6] Abdul Razak, I.R., Yusu, K.N., Salim, M.A. and MohdSalleh, N.B. (2014) Tourism Sea Activities That Cause Damages Towards Coral Reefs in Sembilan Islands. Tourism, Leisure and Global Change, 1, 112-123.

[7] Wilkinson, C.R. (2000) Status of Coral Reefs of the World. Global Coral Reef Monitoring Network and Australian Institute of Marine Science, Townsville, Australia, $363 \mathrm{p}$.

[8] Bryant, D., Burke, L., McManus, J. and Spalding, M. (1998) Reefs at Risk-A Map Based Indicator of Threats to the World's Coral Reefs. WRI/ICLARM/WCMC/UNEP.

[9] Hilmi, N., Safa, A., Reynaud, S. and Allemand, D. (2012) Coral Reefs and Tourism in Egypt's Red Sea. Topics in Middle Eastern and African Economies, 14, 416-434. 
[10] Hawkins, J.P. and Roberts, C.M. (1993) Can Egypt's Coral Reefs Support Ambitious Plans for Diving Tourism? Proceedings of the 7 th International Coral Reef Symposium, Vol. 2, Guam, 22-27 June 1992, 1007-1013.

[11] Barker, N.H.L. and Roberts, C.M. (2004) Scuba Diver Behaviour and the Management of Diving Impacts on Coral Reefs. Biological Conservation, 120, 481-489. https://doi.org/10.1016/j.biocon.2004.03.021

[12] Dinsdale, E.A. and Harriott, V.J. (2004) Assessing Anchor Damage on Coral Reefs: A Case Study in Selection of Environmental Indicators. Environmental Management, 33, 126-139. https://doi.org/10.1007/s00267-003-3056-9

[13] Davenport, J. and Davenport, J. (2006) The Impact of Tourism and Personal Leisure Transport on Coastal Environments: A Review. Estuarine, Coastal and Shelf Science, 67, 280-292. https://doi.org/10.1016/j.ecss.2005.11.026

[14] Jameson, S.C., Ammar, M.S.A., Saadalla, E., Mostafa, H.M. and Riegl, B. (2007) A Quantitative Ecological Assessment of Diving Sites in the Egyptian Red Sea during a Period of Severe Anchor Damage: A Baseline for Restoration and Sustainable Tourism Management. Journal of Sustainable Tourism, 15, 309-322. https://doi.org/10.2167/jost719.0

[15] Abou Zaid, M. (2002) Impact of Diving Activities on the Coral Reefs along the Red Sea Coast of Hurghada. Mimeo Marine Biology and Fish Science, Section, Zoology Department, Al-Azhar University, Cairo, Egypt.

[16] Roger, C.S., Garrison, G., Grober, R., Hillis, Z.M. and Franke, M.A. (1994) Coral Reef Monitoring Manual for the Caribbean and Western Atlantic. Vergin Islands National Park, USA, 112 p.

[17] Wilkinson, C., Green, A., Almany, J. and Dionne, S. (2003) Monitoring Coral Reef Marine Protected Areas-Apractical Guide on How Monitoring Can Support Effective Management of MPAs. Institute of Marine Science, Townsville, Australia, 72 p.

[18] Norusis, M.J. (1990) SPSS Inc., SPSS Advanced Statistics User's Guide. SPSS Inc., IL, USA, 285 p.

[19] Wilkinson, C. (2002) Status of Coral Reefs of the World 2002. Australian Institute of Marine Science (AIMS), Global Coral Reef Monitoring Network (GCRMN), Townsville, Australia.

[20] Cesar, H. (2003) Economic Valuation of the Egyptian Red Sea Coral Reefs. Egyptian Environmental Policy Program, 88 p.

[21] Crosby, M.P., Abo Hilal, A., Al-Homoud, A., Erez, J. and Ortal, R. (2000) Interactions among Scientists, Managers and the Public in Defining Research Priorities and Management Strategies for Marine and Coastal Resources: Is the Red Sea Marine Peace Park a New Paradigm? Water, Air and Soil Pollution, 123, 581-594. https://doi.org/10.1023/A:1005281403279

[22] Hasler-Sheetal, H. and Ott, J. (2008) Diving down the Reefs? Intensive Diving Tourism Threatens the Reefs of the Northern Red Sea. Marine Pollution Bulletin, 56, 1788-1794. https://doi.org/10.1016/j.marpolbul.2008.06.002

[23] Tissot, B.N. and Hallacher, L.E. (2000) Diver Impacts on Corals at Kealakekua Bay. Hawaii. Technical Report, Division of Aquatic Resources, Honolulu, HI, 10 p.

[24] Riegl, B.M., Bruckner, A.W., Rowlands, G.P., Purkis, S.J. and Renaud, P. (2012) Red Sea Coral Reef Trajectories over 2 Decades Suggest Increasing Community Homogenization and Decline in Coral Size. PLoS ONE, 7, e38396.

[25] Riegl, B. and Velmirov, B. (1991) How Many Damaged Corals in Red Sea Reef Systems? A Quantitative Survey. Hydrobiologia, 216, 249-256.

https://doi.org/10.1007/BF00026471 
[26] Jobbins, G. (2006) Tourism and Coral-Reef-Based Conservation: Can Hey Coexist? In: Côté, I.M. and Reynolds, J.D., Eds., Coral Reef Conservation, Cambridge University Press, Cambridge, 237-263. https://doi.org/10.1017/CBO9780511804472.009

[27] Al-Zibdah, M.K., Damhoureyeh, S.A. and Badran, M.I. (2007) Temporal Variations in Coral Reef Health at a Coastal Industrial Site on the Gulf of Aqaba, Red Sea. Oceanologia, 49, 565-578. 